\title{
ПРОБЛЕМЫ АДМИНИСТРАТИВНОГО НАДЗОРА ЗА ЛИЦАМИ, ОСУЖДЕННЫМИ ЗА СОВЕРШЕНИЕ ПРЕСТУПЛЕНИЙ В ОБЛАСТИ ОБОРОТА НАРКОТИКОВ
}

\author{
Н. М. Тюкалова, Н. А. Кулаков \\ Санкт-Петербургский университет МВД России \\ Поступила в редакцию 16 апреля 2021 г.
}

\begin{abstract}
Аннотация: раскрыты результаты исследования проблел правового регулирования адлинистративного надзора за лииали, осужденныли за совершение преступлений в области незаконного оборота наркотических средств и освобожденныли из мест лишения свободы. Сфборлулирован вывод, что институт адлинистративного надзора - эбббективное средство превениии правонарушений в отношении лии, осужденньх за совершение преступлений в области незаконного оборота наркотических средств и освобожденных из мест лишения свободы. Тем не менее колплекс причин законодательного характера не позволяет в полной мере реализовать потенииал данного института в указанной области. В связи с этим предлагается существенно расширить перечень оснований установления адлинистративного надзора за лицали, отбывшили наказание в виде лишения свободы за преступления в области незаконного оборота наркотиков. Форлулируются конкретные предложения по корректировке действующего законодательства.
\end{abstract}

Ключевые слова: наркотизаиия, наркотические средства, психотропные вещества, прекурсоры, психоактивные вещества, оборот наркотиков, контроль, адлинистративный надзор, органь внутренних дел, полииия.

\begin{abstract}
: the article discloses the results of a study of the problems of legal regulation of administrative supervision of persons convicted of crimes in the field of drug trafficking and released from places of imprisonment. The authors concluded in the article that the institution of administrative supervision is an effective means of preventing offenses against persons convicted of crimes in the field of drug trafficking and released from places of deprivation of liberty. Nevertheless, the complex of legislative reasons does not allow to fully realize the potential of this institution in this area. In this regard, the authors propose to significantly expand the list of grounds for establishing administrative supervision of persons who have served a sentence of imprisonment for crimes in the field of drug trafficking, and make specific proposals for adjusting the current legislation.

Key words: narcotization, drugs, psychotropic substances, precursors, psychoactive substances, drug trafficking, control, administrative supervision, law-enforcement bodies, police.
\end{abstract}

Проблема наркопотребления в современном мире остается одной из самых острых и актуальных. Несмотря на прикладываемые мировым сообществом усилия, тенденции на рынке наркооборота приобретают все более устрашающий характер, а объемы потребления наркотиков ста-

(C) Тюкалова Н. М., Кулаков Н. А., 2021 


\section{Вестник ВГУ. Серия: Право}

бильно высоки. Не является исключением в этом смысле и Российская Федерация.

В последние годы все более явным становится тот фракт, что решить проблему наркопотребления и незаконного оборота наркотиков исключительно мерами принуждения не представляется возможным. Ужесточение наказания и борьба с объемами производимых и транспортируемых наркотических средств сами по себе не позволяют достичь положительного результата в рассматриваемой области. Ни уголовное, ни административно-деликтное законодательство не способно в отрыве от мер медико-профилактического и воспитательного характера обеспечить значительного улучшения ситуации в области наркопотребления и незаконного оборота.

Вместе с тем сказанное не означает, что государству следует ослаблять контроль в отношении наркобизнеса. Его представители нередко не останавливаются на совершении первого преступления и продолжают свою преступную деятельность, даже оказавшись привлеченными к уголовной ответственности.

Такая ситуация объясняется сверхприбылью от соответствующего вида деятельности и ее относительной простотой. Как показывает практика, даже отбыв уголовное наказание в виде лишения свободы, рецидив преступлений, связанных с незаконным оборотом наркотиков, очень высок. Около 20 \% от всех лиц, осужденных в 2018-2020 гг. за преступления в области оборота наркотических и психотропных веществ, ранее судимы за аналогичные деяния. При этом около 8 \% из них совершили рецидив, в том числе по $1 \%$ соответственно опасный и особо опасный ${ }^{1}$.

Необходимо обратить внимание еще и на то, что «наркодиллеры» не только обеспечивают функционирование рынка наркотиков, но и направляют определенные усилия на формирование спроса на соответствующую продукцию среди здоровой части общества. Расширение рынка залог прибыли для таких лиц. В связи с этим государственный контроль (надзор) за лицами, ранее осужденными за преступления в области оборота наркотиков, должен быть самым пристальным.

Важным элементом предупреждения правонарушений в области незаконного оборота наркотиков со стороны лиц, ранее осужденных за такие деяния, является институт административного надзора. Отметим, что в теории административного права не сформирован единый подход к содержанию таких понятий, как контроль и надзор. Большая часть специалистов придерживается точки зрения, что контроль - понятие более широкое, чем надзор.

Как отмечал Д. Н. Бахрах, по такому критерию, как объем, следует отличать непосредственно контроль, в рамках которого осуществляется проверка законности и целесообразности той или иной деятельности, и

${ }^{1}$ Статистические фрормы 1-МВ-НОН за 2018-2020 гг. // Официальный сайт судебного департамента РФ. Раздел судебная статистика. URL: http://www.cdep. ru.index.html (дата обращения: 12.04.2021). 
надзор, рамки которого ограничены лишь проверкой деятельности на предмет соответствия закону ${ }^{2}$. Аналогичной позиции придерживается и ряд других специалистов ${ }^{3}$.

Еще одним вариантом разграничения таких категорий, как «контроль» и «надзор», является признание надзорных полномочий исключительной компетенцией органов прокуратуры. Иные органы власти предлагается называть контрольными ${ }^{4}$ C подходом подобного рода сложно согласиться, так как критерием разграничения "контроля» и «надзора» выбран субъект реализации данных функций. На наш взгляд, разграничение государственно-управленческих фрункций должно основываться, прежде всего, на исследовании сущностных признаков и специфрических характеристик таких функций.

В юридической литературе высказывается также мнение, согласно которому под государственным надзором следует понимать проверку соблюдения законности организационно неподчиненными субъектами, а также иные формы деятельности, связанные с наблюдением за функционированием объекта и изданием актов, направленных на предупреждение, выявление и пресечение нарушений законности (такие, как рейд, мониторинговая закупка, инспекционный визит). В свою очередь, учитывая внутриорганизационный характер контрольных фрункций, государственный контроль необходимо сосредоточить сугубо в рамках аппарата государственных органов ${ }^{5}$.

Что же касается легального использования анализируемых терминов, то законодатель ни одну из приведенных выше научных позиций в области разграничения «контроля» и «надзора» учитывать не стал и определил их в качестве синонимов. Под государственным контролем (надзором), муниципальным контролем в Российской Федерации понимается деятельность контрольных (надзорных) органов, направленная на предупреждение, выявление и пресечение нарушений обязательных требований, осуществляемая посредством:

профилактики нарушений обязательных требований;

оценки соблюдения гражданами и организациями обязательных требований, выявления их нарушений;

${ }^{2}$ См.: Бахрах Д. Н., Россинский Б. В., Старилов Ю. Н. Административное право : учебник для вузов. 2-е изд., изм. и доп. М., 2006. С. 354.

${ }^{3}$ См., например: Беляев В. П. Контроль и надзор в Российском государстве. М., 2005. С. 123 ; Козлов Ю. М. Административное право. М., 2005. С. 231 ; Фесько Д. С. Административный контроль (надзор) как функция органов охраны правопорядка // Административное право и процесс. 2018. № 11. С. 74 ; Чанов C. E. Контрольно-надзорная деятельность как самостоятельный способ обеспечения законности // Вестник Саратовской юридической академии. 2016. № 2 (109). С. 178.

${ }^{4}$ См.: Анисимова $K$. О. Понятие и сущность государственного контроля и надзора, проблемы их разграничения // Научный вестник Крыма. 2018. № 4. С. 7.

${ }^{5}$ См.: Дехтярь И. Н. О необходимости законодательного разграничения функций государственного контроля и надзора в аспекте административной реформы // Административное право и процесс. 2020. № 3. С. 55. 
принятия предусмотренных законодательством Российской Федерации мер по пресечению выявленных нарушений обязательных требований, устранению их последствий и (или) восстановлению правового положения, существовавшего до возникновения таких нарушений 6 .

Таким образом, рассматриваемые категории в современной российской правовой действительности не следует воспринимать в качестве различных направлений государственно-управленческой деятельности. $\mathrm{C}$ точки зрения действующего закона категории «контроль» и «надзор» неотделимы друг от друга и используются как синонимы.

Обратим внимание на то, что Федеральный закон «О государственном контроле (надзоре) и муниципальном контроле в Российской Федерации», большая часть норм которого вступила в силу с 1 июля 2021 г., в качестве объекта государственного контроля (надзора) называет, в частности, поведение (действия, деятельность) граждан. До принятия анализируемого законодательного акта определение государственного контроля (надзора) содержалось в ст. 2 Федерального закона от 26 декабря 2008 г. № 294-Ф3 «О защите прав юридических лиц и индивидуальных предпринимателей при осуществлении государственного контроля (надзора) и муниципального контроля» ${ }^{7}$. Данное определение включало в объект контроля (надзора) лишь деятельность юридических лиц и индивидуальных предпринимателей. Поведение же граждан из объекта государственного контроля (надзора) выпадало. В связи с этим имела место правовая неопределенность относительно того, охватывается ли административный надзор за лицами, освобожденными из мест лишения свободы, законодательным понятием государственный контроль (надзор). С этой точки зрения дефиниция, сформулированная законодателем в ст. 1 Федерального закона от 31 июля 2020 г. № 248-ФЗ «О государственном контроле (надзоре) и муниципальном контроле в Российской Федерации» представляется более полной.

Административный надзор за лицами, освобожденными из мест лишения свободы, является одним из примеров государственных контрольно-надзорных функций. Осуществляется данный вид надзора в отношении лиц, ранее отбывших уголовное наказание в виде лишения

188 свободы. Для установления в отношении лица административного надзора требуется наличие юридического состава (совокупности нескольких юридических фрактов), предусмотренного ст. 3 Федерального закона от 6 апреля 2011 г. № 64-Ф3 «Об административном надзоре за лицами, освобожденными из мест лишения свободы» ${ }^{8}$ (далее - Ф3 «Об административном надзоре»).

${ }^{6}$ О государственном контроле (надзоре) и муниципальном контроле в Российской Федерации : федер. закон от 31 июля 2020 г. № 248-Ф3 // Рос. газета. 2020. 5 авг.

${ }^{7}$ Рос. газета. 2008. 30 дек.

${ }^{8}$ Об административном надзоре за лицами, освобожденными из мест лишения свободы : федер. закон от 6 апреля 2011 г. № 64-ФЗ // Рос. газета. 2011. 8 апр. 
Административный надзор устанавливается решением суда и предполагает применение в отношении поднадзорного лица определенных законом ограничительных мер, направленных, прежде всего, на предупреждение совершения данным лицом правонарушений. Непосредственно административный надзор (наблюдение за поднадзорным, проверка соблюдения им установленных ограничений, реагирование на их нарушение) осуществляется органами внутренних дел, а конкретнее - подразделениями участковых уполномоченных полиции.

Можно выделить три варианта установления административного надзора в отношении лица, отбывшего наказание в виде лишения свободы. Первые два могут иметь место, когда лицо освободилось из мест лишения свободы, где отбыло наказание за совершение:

тяжкого или особо тяжкого преступления;

рецидива преступлений;

умышленного преступления в отношении несовершеннолетнего;

двух и более преступлений в области незаконного оборота наркотиков и иных аналогичных веществ, предусмотренных ч. 1 ст. 228, 228.3, ч. 1 ст. 231, ч. 1 ст. 234.1 УК РФ.

При наличии хотя бы одного из перечисленных критериев административный надзор может быть установлен:

по инициативе администрации исправительного учреждения, в котором поднадзорный отбывал наказание (в случаях, когда данное лицо в период отбывания наказания признано злостным нарушителем установленного порядка отбывания наказания);

по инициативе участкового уполномоченного полиции в случаях, когда лицо, отбывшее наказание и имеющее судимость, в течение года после освобождения совершает два и более административных правонарушения, посягающих на порядок управления, общественный порядок и некоторые другие объекты административно-деликтной охраны (см. п. 2 ч. 3 ст. 3 ФЗ «Об административном надзоре»).

Кроме того, ФЗ «Об административном надзоре» предусматривает и третий вариант установления административного надзора, когда соответствующие меры применяются в обязательном порядке независимо от наличия перечисленных выше оснований. В таком порядке административный надзор, например, устанавливается в отношении совершеннолетнего лица, освобожденного из мест лишения свободы, имеющего судимость за совершение преступления при опасном или особо опасном рецидиве (см. п. 2 ч. 2 ст. 3 ФЗ «Об административном надзоре»).

В связи с высоким рецидивом правонарушений в области незаконного оборота наркотиков роль института административного надзора за лицами, освобожденными из мест лишения свободы, возрастает. Поэтому, на наш взгляд, критического осмысления требуют правовые основания установления данной меры административного принуждения в отношении лиц, осужденных за преступления в области незаконного оборота наркотиков по частям первым ст. 228, 234.1, 231, 228.3 УК РФ. Как отмечалось выше, для установления в отношении таких лиц адми- 
нистративного надзора после отбытия уголовного наказания в виде лишения свободы требуется совершение ими «двух и более преступлений» соответствующего характера.

Представляется, что если лицо, однажды отбыв лишение свободы, продолжило нарушать законодательство в области оборота наркотиков, то можно прийти к выводу о неэффективности мер уголовно-правового и административного характера в отношении данного лица. Применение к такому лицу мер административного надзора вполне оправданно уже только на том основании, что им совершено преступление в области незаконного оборота наркотиков. Если лицо осуждено к лишению свободы за совершение преступления в области незаконного оборота наркотиков средней тяжести, то установление в отношении его административного надзора должно быть обусловлено дополнительными основаниями, предусмотренными п. 2 ч. 3 ст. 3 ФЗ «Об административном надзоре». Если же лицо осуждено к лишению свободы за совершение тяжкого или особо тяжкого преступления в области оборота наркотиков, то меры административного надзора должны применяться к нему сразу после освобождения независимо от наличия дополнительных оснований.

В связи с этим представляется целесообразным расшить перечень составов преступлений, осуждение и отбытие наказания по которым влечет установление административного надзора после отбытия наказания. Предлагается п. 4 ч. 1 ст. 3 ФЗ «Об административном надзоре» изложить в следующей редакции: «совершение преступления средней тяжести, предусмотренного статьями 228-234 УК РФ». В свою очередь ч. 2 ст. 3 ФЗ «Об административном надзоре» следует дополнить подп. 5 следующего содержания: «совершение тяжкого или особо тяжкого преступления, предусмотренного статьями 228-234 УК РФ».

Отметим, что подобный подход применяется законодателем в ряде стран СНГ, в которых существует институт административного надзора. В качестве примеров можно привести Казахстан и Украину. В соответствии с Законом Украины от 1 декабря 1994 г. № 264/94-ВР «Об административном надзоре за лицами, освобожденными из мест лишения свободы» и одноименному Закону Республики Казахстан от 15 июня 1996 г. № 28-1 осужденные «за одно из преступлений, связанных с незаконным оборотом наркотиков», становятся поднадзорными без учета количества преступлений» ${ }^{9}$.

Противодействие незаконному обороту наркотических средств может быть эфрфективным исключительно на основе сочетания мер принудительного характера с мерами профилактического и реабилитационного характера. Важным элементом предупреждения правонарушений в области незаконного оборота наркотиков и противодействия наркотизации населения является институт административного надзора за лицами,

${ }^{9}$ Савинков A. A. Некоторые меры предупреждения преступности, связанной со склонением к потреблению наркотических средств, психотропных веществ или их аналогов // Российский следователь. 2018. № 10. С. 65. 
отбывшими уголовное наказание в виде лишения свободы за преступления в области незаконного оборота наркотиков. Действующее законодательство содержит потенциал для расширения перечня оснований применения мер административного надзора в отношении соответствующей категории граждан.

\section{Библиографический список}

Анисилова $K$. O. Понятие и сущность государственного контроля и надзора, проблемы их разграничения // Научный вестник Крыма. 2018. № 4. C. 7-12.

Бахрах Д. Н., Россинский Б. В., Старилов Ю. Н. Административное право : учебник для вузов. 2-е изд., изм. и доп. М., 2006.

Беляев В. П. Контроль и надзор в Российском государстве. М., 2005.

Дехтярь И. Н. О необходимости законодательного разграничения фуункций государственного контроля и надзора в аспекте административной реформы // Административное право и процесс. 2020. № 3. С. 55-63.

Козлов Ю. М. Административное право. М., 2005.

Савинков $A$. A. Некоторые меры предупреждения преступности, связанной со склонением к потреблению наркотических средств, психотропных веществ или их аналогов // Российский следователь. 2018. № 10.

Фесько Д. С. Административный контроль (надзор) как фонкция органов охраны правопорядка // Административное право и процесс. 2018. № 11.

Чанов C. E. Контрольно-надзорная деятельность как самостоятельный способ обеспечения законности // Вестник Саратовской юрид. академии. 2016. № 2 (109).

\section{References}

Anisimova K. O. The concept and essence of state control and supervision, the problems of their demarcation//Scientific Bulletin of Crimea. 2018. № 4. P. 7-12.

Bakhrakh D. N., Rossinsky B. V., Starilov Yu. N. Administrative law: textbook for universities. 2nd ed., Ism and additional. M., 2006.

Belyaev V. P. Control and supervision in the Russian state. M., 2005.

Dechtyar I. N. On the need for a legislative distinction between the functions of state control and supervision in the aspect of administrative reform //Administrative law and process. 2020. № 3. P. 55-63.

Kozlov Yu. M. Administrative law. M., 2005.

Savinkov A. A. Some measures to prevent crime associated with the tendency to consume narcotic drugs, psychotropic substances or their analogues// Russian investigator. 2018. № 10 .

Fesko D. S. Administrative control (supervision) as a function of law enforcement agencies // Administrative law and process. 2018. № 11.

Chanov $S$. E. Control and supervisory activity as an independent way to ensure the rule of law // Bulletin of the Saratov Law Academy. 2016. № 2 (109).

\section{Для иитирования:}

Тюкалова Н. М., Кулаков Н. А. Проблемы административного надзора за лицами, осужденными за совершение преступлений в области оборота наркотиков // Вестник Воронежского государственного университета. Серия: Право. 2021. № 3 (46). C. 185-192. DOI: https://doi.org/10.17308/vsu.proc.law.2021.3/3620 


\section{Вестник ВГУ. Серия: Право}

\section{Recommended citation:}

Tyukalova N. M., Kulakov N. A. Problems of administrative supervision of drug trafficking offenders // Proceedings of Voronezh State University. Series: Law. 2021. № 3 (46). P. 185-192. DOI: https://doi.org/10.17308/vsu.proc.law.2021.3/3620

Санкт-Петербургский университет МВД России

Тюкалова Н. М., кандидат юридических наук, дочент, профессор кафедрь административного права

E-mail:n.tyukalova@mail.ru

Кулаков Н. А., кандидат юридических наук, доцент кафбедры административной деятельности органов внутренних дел

E-mail:2-kvadrat@mail.ru
St. Petersburg University of the Ministry of Internal Affairs of the Russian Federation

Tyukalova N. M., Candidate of Legal Sciences, Associate Professor, Professor of the Administrative Law Department

E-mail: n.tyukalova@mail.ru

Kulakov N. A., Candidate of Legal Sciences, Associate Professor of the Administrative Activities of Internal Affairs Bodies Department

E-mail:2-kvadrat@mail.ru 